\title{
Attempts to Identify Cassava Brown Streak Virus in Western Democratic Republic of Congo
}

\author{
Bakelana Zeyimo ${ }^{1,10}$, Magembe Eric ${ }^{2,8}$, Laura Boykin ${ }^{5}$, Mercy Macharia $^{2}$, Mahungu Nzola $^{3}$, Tata-Hangy ${ }^{3}$, \\ Lutete Diankenda ${ }^{4}$, Monde Godefroid ${ }^{6}$, Jagger Harvey ${ }^{2,11}$, Joseph Ndunguru ${ }^{7}$, Charles Kayuki ${ }^{7}$, Justin Pita ${ }^{9}$, \\ Lema Munseki ${ }^{10} \&$ Tshilenge Kanana ${ }^{10}$ \\ ${ }^{1}$ National Institute for Agricultural Research and Studies (INERA), DR, Congo \\ ${ }^{2}$ Biosciences for Eastern and Central Africa, International Livestock Research Institute (BecA-ILRI Hub), \\ Nairobi, Kenya \\ ${ }^{3}$ International Institute of Tropical Agriculture (IITA), Ibadan, Oyo State, Nigeria \\ ${ }^{4}$ Food and Alimentation Organization (FAO), DR, Congo \\ ${ }^{5}$ School of Molecular Sciences and Australian Research Council Centre of Excellence in Plant Energy Biology, \\ University of Western Australia, Crawley, Perth, WA, Australia \\ ${ }^{6}$ Institute Faculty of Agricultural Sciences, Yangambi, DR, Congo \\ ${ }^{7}$ Mikocheni Agriculture Research Institute (MARI), Dar-es-Salaam, Tanzania \\ ${ }^{8}$ University of Nairobi, Kenya \\ ${ }^{9}$ West African Virus Epidemiology (WAVE), Abidjan, Cote d'Ivoire \\ ${ }^{10}$ Agriculture Faculty, Kinshasa University, DR, Congo \\ ${ }^{11}$ Feed the Future Innovation Lab for the Reduction of Post-Harvest Loss, Department of Plant Pathology, \\ Kansas State University, Manhatttan, Kansas, USA \\ Correspondence: Bakelana Zeyimo, National Institute for Agricultural Research and Studies (INERA), DR, \\ Congo. E-mail: bakelanatony@hotmail.com
}

Received: October 2, 2018

doi:10.5539/jas.v11n2p31
Accepted: November 17, $2018 \quad$ Online Published: January 15, 2019

URL: https://doi.org/10.5539/jas.v11n2p31

\begin{abstract}
Root necrosis similar to those of the cassava brown streak disease (CBSD) were observed on cassava in western provinces of the Democratic Republic of Congo (DR.Congo) in the early 2000's. However molecular laboratory diagnosis were not able to detect any causative agent responsible for the attacks, hence, the disease related to these symptoms was named CBSD-like disease.

In order to assess the distribution and the incidence of the CBSD-like disease, surveys were carried out in four western provinces, comprising, Kwango and Kwilu, Sud Ubangi, Kinshasa and Kongo Central. CBSD-like disease was observed in all surveyed provinces on the basis of root symptoms because foliar symptoms were different to those of the documented cases of CBSD in other parts of east Africa. CBSD-like disease incidence was high in Kongo Central and Sud Ubangi, exceeding an average of $50 \%$, but low in Kwango and Kwilu $(32.8 \%)$ and in Kinshasa (19.1\%).

During the surveys, cassava leaf samples were collected for lab identification of the causal agent. PCR diagnosis was done on these samples using primers specific for the two known CBSVs. All samples tested negative with no amplification of DNA fragments of the correct size. Thus, further analysis on the causative organism is needed using Next Generation Sequencing (NGS) approaches. NGS approaches will help also to identify the causative organism in other Central Africa countries (Angola, Congo-Brazzaville and Gabon) where such cassava root necrosis have been reported or are suspected.
\end{abstract}

Keywords: Cassava Brown Streak Like Virus, Democratic Republic of Congo, PCR, root necrosis, surveys 


\section{Introduction}

Cassava (Manihot esculenta Crantz) is one of the food crops that is extensively cultivated in the Sub-Saharan Africa. Its total production is estimated at more than 121 millions of tons, which is more than any other crop in Africa (FAO, 2006) and $54 \%$ of the world production (FAO, 2003).

Cassava is very important for small holder farmers because of its role in food security and as source of incomes (Fauquet \& Fargette, 1990; Harrison et al., 1997). However, cassava yields still remains low at 8-9 tons/ha which is about $70 \%$ of what is obtained in South America and 61\% in Asia (Legg \& Thresh, 2003).The total production of cassava in DR, Congo was recorded at 15,020,000 tons (FAOSTAT, 2009).

Cassava production in Africa is mostly constrained by pests and diseases (Hahn \& Keyser, 1985). Cassava mosaic disease (CMD) caused by cassava mosaic geminiviruses (CMGs) (Geminiviridae; Begomovirus) is undoubtedly the most important constraint to the production of cassava in Africa at the outset of the 21st century (Legg \& Fauquet, 2004).

The most visible symptom of the disease is the expression of the characteristic leaf mosaic, and young plants are more severely affected than old ones. Symptoms range from barely perceptible mosaic to stunting of the plant and extreme reduction of the leaf blades (Fauquet \& Fargette, 1990).

Epidemics of CMD are very devastating with yield losses varying between 20 to $90 \%$ (Hahn et al., 1980; Muimba \& Phuti, 1987; Fauquet \& Fargette, 1990) depending on the virus strain.

In the 2000s, DR, Congo experienced a severe outbreak of the CMD by the Ugandan variant (EACMV-UG) which was detected in most of cassava growing areas in the country resulting in significant crop losses (Lema et al., 2004; Tata-Hangy et al., 2004).

Cassava brown streak disease (CBSD) is another viral disease that constrains cassava production in most parts of East African region. Hillocks et al., 2001 estimated loss in the fresh roots yield due to CBSD at more than $70 \%$. It was recognized for long as being endemic in the inshore of cassava areas in the coastal zones (Storey, 1936; Rwegasira et al., 2011) and limited to low and mid altitudes below 1000 meters (Nichols, 1950). However, from 2004, outbreaks were reported at altitudes greater than 1000 meters in the Great lakes region of east and central Africa (Alicai et al., 2007). Currently, CBSD is occurring in various eastern and southern African countries including Kenya, Malawi, Mozambique, Tanzania and Uganda (Alicai et al., 2007). More recently, CBSD has been reported in eastern DR, Congo and confirmed at molecular level (Mulimbi et al., 2012).

Leaf symptoms include blotchy yellow chlorosis or feathery necrosis, often associated with minor veins, which can appear within the first few months after planting of infected cuttings and persist in mature leaves. Brown, round or elongate streak-like lesions can occur on the young green portion of infected stems, but the main economic loss is caused by dry, brown necrotic lesions in the storage tissues of the tuberous roots of infected susceptible plants (Storey, 1936; Legg et al., 2011). Root constrictions are also sometimes observed as well as brown/black lesions on green fruits, and necrotic lesions in leaf scars. In severe infections these lesions develop to kill the dormant axilliary buds leading to a general shrinkage of the node and death of the intermodal tissue, so that the branch dies from the tip to cause 'dieback' (Hillocks \& Jennings, 2003). Secondary losses occur as a consequence of early harvesting, which farmers use as a strategy to avoid root necrosis (Hillocks, 2003).

CBSD causes economic damages on tuberous roots in form of yellow/brown necrosis bearing tissues which became unfit for human consumption (Hillocks \& Jennings, 2003).

CBSD is known to be caused by a RNA (ssRNA) virus of the family Potyviridae; genus Ipomovirus (Monger et al., 2001a). Two genetically distinct strains of CBSVs were recognized in East Africa (Mbazibwa et al., 2009), which are shown to be two distinct species, Cassava brown streak virus (classic) and Ugandan cassava brown streak virus (Monger et al., 2010).

In early 2000s, cassava root necrosis (Figure 1) similar to those of CBSD were reported in western provinces of DR.Congo (Kinshasa and Kongo Central) by Mahungu et al. (2003) and up to date PCR diagnoses did not detect any causal agent related to the observed symptoms and the disease is still referred to as 'CBSD-like disease'. 

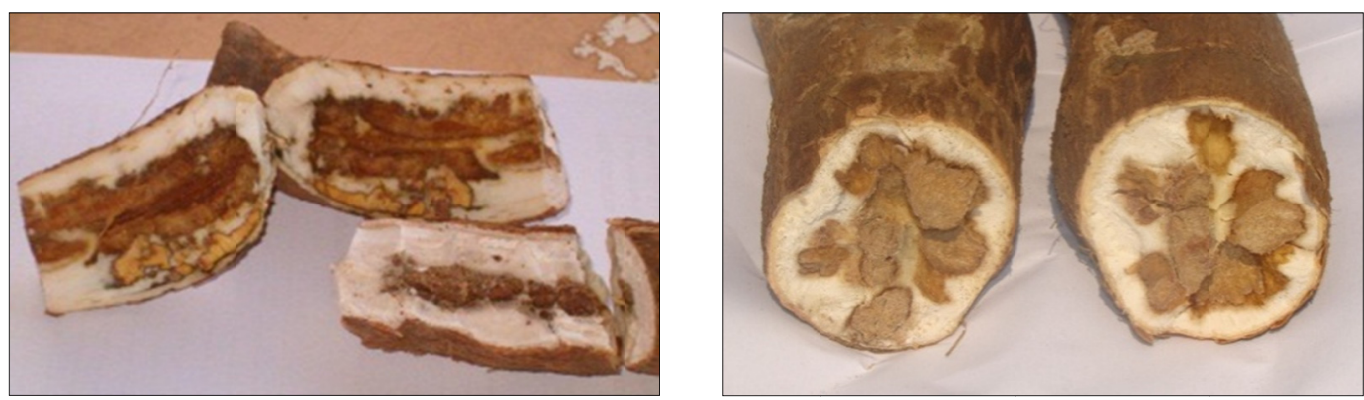

Figure 1. Typical root necrosis of CBSD-like disease observed in western DR.Congo

Several attempts to identify the causative agent responsible for CBSD-like disease in western DR, Congo have been undertaken since 2004 using cassava leaf samples, including those from plants showing very severe symptoms, with no success to date.

CBSD can be detected from non-necrotic cortical root tissue, peelings from tender stem, young tender leaves, flowers, fruits, youngest symptomatic leaves and mature leaves with clear symptoms. This suggest that most portions of infected cassava plants could be used to sample for CBSV (Rwegasira, 2011).

This study describes the molecular diagnosis attempts that were carried out from 2012 to 2017 at BecA/Nairobi, IITA Tanzania, IITA Nigeria and MARI in Tanzania, using all available CBSVs primers from eastern Africa.

\section{Materials and Methods}

\subsection{Sample Collection}

In order to assess the distribution and the incidence of the CBSD-like disease, a survey was carried out in 2012 in 4 large provinces of western DR, Congo comprising; Kongo Central, Kinshasa, Kwango, Kwilu and Sud-Ubangi (Figure 2). Leaves were sampled along main roads at regular intervals of $5 \mathrm{kms}$. Thirty plants were randomly selected on two diagonals in each of the field. Diseases and pests severity and GPS coordinates were recorded. Particular attention was given to CBSD-like root necrosis symptoms. When more than one cassava variety was found in a field, sampling was done on the most prevalent variety. CBSD-like root severity were assessed using a scale of $1-5$, where, $1=$ no apparent necrosis, $2=$ less than $5 \%$ root necrosis, $3=5-10 \%$ root necrosis, $4=10-25 \%$ root necrosis, mild root constriction and $5=>25 \%$ root necrosis with severe root constrictions (Abaca, 2012). CBSD-like root necrosis incidence was calculated as percent by dividing the number of diseased plants by the total number of plants sampled in a field.

\subsection{Molecular Diagnosis}

For molecular diagnosis, leaf samples were collected from plants that had been sampled earlier along diagonals in the field on every third plants, making one set of 10 samples. For each of the plants sampled, the central leaflet was picked from the second fully-expanded leaf (counting from the shoot apex). This leaflet was fixed onto a sheet of blank newsprint using masking tape. Ten leaflets obtained from ten plants of the same field were placed on a single blank newsprint sheet and kept as herbarium. A total of 1450 leaf samples were collected from 145 fields. 


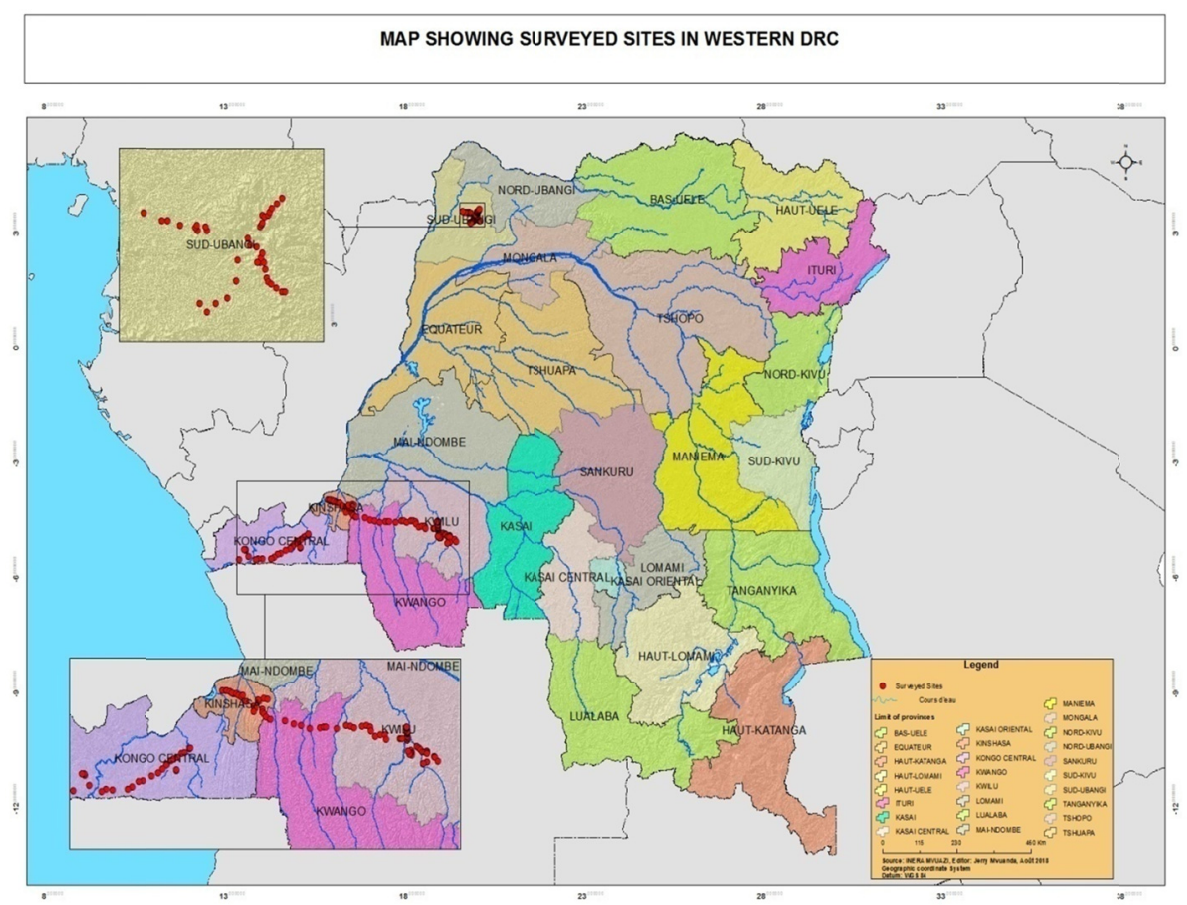

Figure 2. Western DR, Congo provinces where CBSD-like samples were collected

All collected leaf samples were shipped to BecA in Nairobi/Kenya, to IITA/Tanzania, to IITA/Nigeria and to MARI in Tanzania, for laboratory processing and analyses. In the laboratory, DNA and RNA were extracted from the samples using a modified CTAB procedure (Maruthi et al., 2002). Leaves were ground using the Genogrinder machine. Positive control samples with known virus infection were obtained from the Kenya Plant Health Inspectorate Service (KEPHIS) and another reliable CBSV positive control sample was requested from IITA-Tanzania as dried RNA pellet and re-suspended in $100 \mu \mathrm{l}$ of Tris-EDTA solution. The quantity and quality of the extracted DNA and RNA was determined using the Nanodrop ${ }^{\circledR}$ 2000C spectrophotometer and Agarose (0.8\%) gel electrophoresis stained with Gel Red TM (Biotium USA) $(2.5 \mu \mathrm{l} / 100 \mathrm{ml})$. Genomic DNA was normalized to a final concentration of $10 \mathrm{ng} / \mu \mathrm{l}$ for PCR. The normalized genomic DNA was subjected to PCR amplification using CBSVs diagnostic primers designated by Abarshi et al. (2012) (Table 1).

Table 1. List of primers used for CBSVs amplification

\begin{tabular}{|c|c|c|c|}
\hline Primer name & Sequences & Target virus & Reference \\
\hline CBSV10 & ATCAGAATAGTGTGAACTGCTGG & \multirow{2}{*}{ CBSVs } & \multirow{2}{*}{ Monger et al. (2001) } \\
\hline CBSV11 & ATGCTGGGGTACAGACAAG & & \\
\hline CBSVF2 & GGRCCATACATYAARTGGTT & \multirow{2}{*}{ CBSVs } & \multirow{2}{*}{ Abarshi et al. (2012) } \\
\hline CBSVF3 & GGARCCRATGTAYAAATTTGC & & \\
\hline CBSVR3 & AGGAGCWGCTARWGCAAA & \multirow{2}{*}{ CBSVs } & \multirow{2}{*}{ Abarshi et al. (2012) } \\
\hline CBSVF5 & CCTCCATCWCAYGCWATAGA & & \\
\hline CBSVR7 & CCCTTTGCAAARCTRAAATARC & CBSV & \multirow{2}{*}{ Abarshi et al. (2012) } \\
\hline CBSVR8 & CCATTRTCTYTCCAMADCTTC & CBSUV & \\
\hline
\end{tabular}

For most of the PCR assays, the Bionneer AccuPower PCR PreMix tubes were used. cDNA synthesis was performed using the Accupower Cycle Script RT PreMix (dT20) (Bioneer USA) following the manufacturer's instructions. Each reaction consisted of $18 \mu \mathrm{l}$ of DEPC-DW (diethylpyrocarbonate and distillated water) and $2 \mu 1$ of RNA. The RT-PCR program was as follows: $45^{\circ} \mathrm{C}$ for $60 \mathrm{~min}, 95{ }^{\circ} \mathrm{C}$ for $5 \mathrm{~min}$. The cDNA quality was checked by using the Meisa 1 gene primer to get the expected size at $900 \mathrm{bp}$.

For PCR diagnosis, a reaction of $20 \mu \mathrm{l}$ in Bioneer premix (Bioneer USA) consisting $0.5 \mu 1$ of $0.5 \mu \mathrm{M}$ forward and $0.5 \mu \mathrm{l}$ of $0.5 \mu \mathrm{M}$ reverse primers, $2 \mu \mathrm{l} \mathrm{cDNA}$ and $17 \mu \mathrm{l}$ of distilled water. A thermal cycler reaction profile 
was set with initial denaturation $94{ }^{\circ} \mathrm{C}$ for 5 minutes, 35 cycles denaturation of $94{ }^{\circ} \mathrm{C}$ for $30 \mathrm{~s}$, annealing $58{ }^{\circ} \mathrm{C}$ for $30 \mathrm{~s}$, extension $72{ }^{\circ} \mathrm{C}$ for $1 \mathrm{~min}$ and final extension of $72{ }^{\circ} \mathrm{C}$ for $10 \mathrm{~m}$. PCR products were analyzed by electrophoresis in $1 \times$ TAE buffer on $2 \%$ agarose gel stained with gel red and image captured by a camera under uv light.

Unfortunately, the amplification of one step PCR didn't give very clear amplification with gel band of the correct size for the positive sample. Therefore a nested PCR using CBSVF3 \& CBSVR3 primers on the PCR products of CBSVF5 \& CBSVR5 primers was set in an attempt to get better results. After the run of the nested PCR, no DNA amplification was observed except for the CBSV positive control.

Since all CBSVs primers did not help to identify any CBSVs in any sample collected from western DR, Congo, universal potyvirus primers and TAS-ELISA kits were too tried but failed too to identify any virus in these samples.

\section{Results}

Based on root necrosis symptoms, CBSD-like disease was observed throughout the four surveyed provinces in western DR.Congo. The incidence of the disease evaluated in the field showed CBSD-like symptoms in 18 fields out of 28 sampled fields (64.3\%) in Kongo Central. CBSD-like symptoms were also observed in 20 fields out of 53 sampled fields (37.7\%) in Kwango and Kwilu provinces, 12 fields out of 41 in Sud Ubangi province (29.3\%), and 8 fields out of 23 in Kinshasa (34.8\%). The incidence of infected plants in the field varied from 2 to $78 \%$. The province of Kongo Central had the highest prevalence of the disease in the field. Table 2 shows data on the presence of CBSD-like necrosis in each of the province visited. These results indicate that CBSD-like disease is widely distributed in western DR, Congo. Diseased plants incidence was high in Kongo central and Sud Ubangi, exceeding an average of $50 \%$ and lowest in Kinshasa (19.1\%). Despite the difference in diseased plants incidence between the surveyed provinces, there was no evidence for a significant difference in the severity when comparing affected fields. Such wide distribution of the disease coupled to high incidence of diseased plants in the visited fields are the indications that CBSD-like disease is a real threat to cassava in the surveyed provinces.

Table 2. Summary of data on CBSD-like necrosis collected during the survey in the western provinces of DR, Congo

\begin{tabular}{llll}
\hline Province & Number of sampled field & $\begin{array}{l}\text { Number of field with } \\
\text { CBSD-like root necrosis }\end{array}$ & $\begin{array}{l}\text { \% of plants with CBSD-like } \\
\text { root necrosis (Average) }\end{array}$ \\
\hline Kongo Central & 28 & 18 & 59.2 \\
Kwango and Kwilu & 53 & 20 & 32.8 \\
Sud Ubangi & 41 & 12 & 50.2 \\
Kinshasa & 23 & 8 & 19.1 \\
\hline
\end{tabular}

Molecular diagnosis results from 5 different laboratories, using primers specific for the two known CBSVs strains (CBSV and UCBSV) showed all collected leaf samples from the surveyed provinces, were negative for CBSVs (Figure 3). This suggests that the causative agent of the CBSD-like disease in western DR, Congo could be different from those known at present.

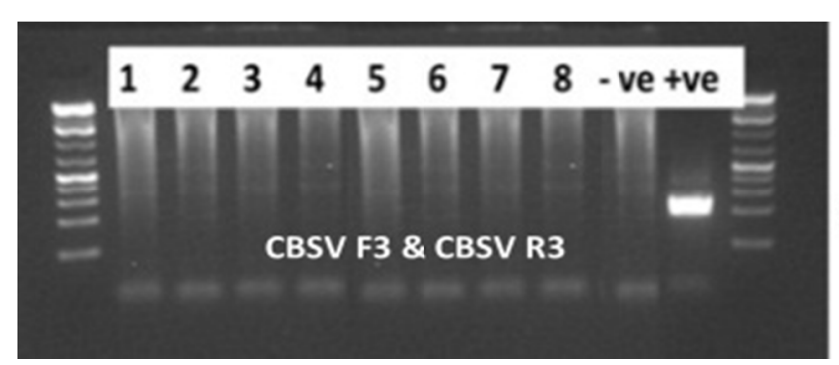

283 bp

Figure 3. PCR results on western DR, Congo CBSD like symptomatic samples using CBSV F3 and CBSV R3 primers. Samples 1-8 are negative, -ve control is positive (+ve control is from East Africa) 
Using molecular analysis, Mulimbi et al. (2012) confirmed CBSV (more specifically the UCBSV) to be present in eastern DR, Congo. All our results CBSV PCR assays are conform to all previous negative results from earlier investigators in western DR, Congo.

\section{Discussion}

Results on the distribution and incidence of the CBSD-like disease in the four surveyed provinces in western DR, Congo suggest that more attention needs to be given in the immediate future to the potential risk of this new type of CBSD or new disease in the country. Urgent interventions are needed, based first on the identification of the causal agent, and further, on the mitigation of the disease that will consists in the development of resistant varieties as a major component of an integrated management approach.

Deep sequencing of freshly collected infected cassava leaves using next-generation sequencing of polyA + RNA and small RNAs should be recommended to elucidate the causes of CBSD-like symptoms in western DR, Congo. This approach has also the potential to discover novel viruses.

Since these viruses have only recently been recognized, descriptions of further CBSD causing viruses can be expected (Ndunguru et al., 2015). Robertson et al. (1991) and Omunyin et al. (1996) stated that based on the nucleotide sequence information of several different viruses, specific primers are designed and used in PCR to detect and differentiate viruses at the family, genus, or strain level. Also, simultaneous detection of unrelated viruses in a sample by using a mixture of virus-specific primer is possible ("Multiplex" PCR) (Bariana et al., 1994; Abarshi et al., 2012).

It is known also that the polyphagous nature of $B$. tabaci may contribute to biotype variability in virus transmission (Brown \& Bird, 1992; Bedford et al., 1994; Markham et al., 1996), and that several factors, such as; the different rates of morphological variation in endosymbionts (Costa et al., 1995); the differences in host utilization (Brown \& Bird, 1992; Bedford et al., 1994a); the ability to induce physiological changes in some hosts (Costa \& Brown, 1991; Cohen et al., 1992; Bedford et al., 1994), and the occurrence of esterase and DNA profile differences (Legg, 1994; Brown et al., 1995) are related to biotype variability. These considerations imply that $B$. tabaci samples should be also collected and submitted to lab analyses in addition to leaf samples for CBSD-like causal agent identification.

Data collected from deep sequencing in DR, Congo samples can be used to develop molecular diagnostic assays for the causative agents in western DR, Congo and others the central African countries (Congo Republic, Angola, Central Africa and Gabon) where CBSD-like symptoms are suspected.

\section{Acknowledgements}

Field surveys and laboratory analyzes were conducted with the financial and technical support of several partners of the INERA National Cassava Program, to whom we have to express our gratitude.

We would like to thank FAO/DR, Congo for providing financial resources through IITA which allowed the survey and samples collections across different DR, Congo western provinces.

We thank BecA by providing to us a grant through the ABCF (African Bioscience Challenge Program), which financially and technically supported in 2012 our 5-months stay to Kenya in Nairobi for laboratory analyzes.

We think IITA, who technically supported us during this long process and provided to us essential informations on previous negative tests carried out in different IITA laboratories.

We thank MARI for giving us this opportunity to visit his laboratory in 2015 in Dar-es-Salaam in order to confirm results previously obtained at BecA.

We are also grateful for the WAVE program which recently has allowed us to confirm at the NGS level, these negative results previously obtained by using PCR.

We cannot forget all farmers and producers who allowed us to collect leaves samples in their cassava fields.

\section{References}

Abaca, A., Kawuki, S. R., Tukamuhabwa, P., Baguma, Y., Pariyo, A., Orone, J., ... Omongo, C. A. (2012). Progression of Cassava Brown Streak Disease (CBSD) in infected cassava roots in Uganda. Uganda Journal of Agriculture Sciences, 13(1), 45-51.

Abarshi, M. M., Mohammed, I. U., Jeremiah, S. C., Legg, J. P., Kumar, L., Hillocks, R. J., \& Maruthi, M. N. (2012). Multiplex RT-PCR assays forthe simultaneous detection of both RNA and DNA viruses infecting cassava and the common occurrence of mixed infections by two cassava brown streak viruses in East Africa. Journal of Virological Methods, 179(1), 176-184. https://doi.org/10.1016/j.jviromet.2011.10.020 
Alicai, T., Omongo, C. A., Maruthi, M. N., Hillocks, R. J., Baguma, Y., Kawuki, R., ... Colvin, J. (2007). Re-emergence of cassava brown streak disease in Uganda. Plant Disease, 91, 24-29. https://oi.org/10.10 94/PD-91-0024

Bariana, H. S., Shannon, A. L., Chu, P. W. G., \& Waterhouse, P. M. (1994). Detection of five seedborne legume viruses in one sensitive multiplex polymerase chain reaction test. Phytopathology, 84, 1201-1205. https://doi.org/10.1094/Phyto-84-1201

Bedford, I. D., Briddon, R. W., Brown, J. K, Rosell, R. C., \& Markham, P. G. (1994). Geminivirus transmission and biological characterisation of Bemisia tabaci (Gennadius) from different geographic regions. Annals of Applied Biology, 125, 311-325. https://doi.org/10.1111/j.1744-7348.1994.tb04972.x

Brown, J. K., \& Bird, J. (1992). Whitefly-transmitted geminiviruses in the Americas and the Caribbean Basin: past and present. Plant Disease, 76, 220-225. https://doi.org/10.1094/PD-76-0220

Brown, J. K., Frohlich, D. R., \& Rosell, R. C. (1995). The sweetpotato or silverleaf whiteflies: Biotypes of Bemisia tabaci or a species complex? Annual Review of Entomology, 40, 511-534. https://doi.org/10.1146/ annurev.en.40.010195.002455

Cohen, S., Duffus, J. E., \& Liu, H. Y. (1992). A new Bemisia tabaci biotype in the southwestern united states and its role in silverleaf of squash and transmission of lettuce infectious yellows virus. Phytopathology, 82, 86-90. https://doi.org/10.1094/Phyto-82-86

Costa, H. S., \& Brown, J. K. (1991). Variation in biological characteristics and esterase patterns among populations of Bemisia tabaci, and the association of one population with silverleaf symptom induction. Entomol. Exp. Appl., 61, 211-219. https://doi.org/10.1111/j.1570-7458.1991.tb01553.x

FAO (Food and Agriculture Organization of the United Nations). (2003). Cassava production statistics. Retrieved from http://www.fao.org/es/ess/top/country.htm

FAO (Food and Agriculture Organization of the United Nations). (2006). Cassava production statistics. Retrieved from http://www.fao.org/es/ess/top/country.htm

FAOSTAT. (2009). FAO Database. Food and Agriculture Organization of theUnited Nations, Rome, Italy.

Fauquet, C., \& Fargette, D. (1990). African cassava mosaic virus: Aetiology, epidemiology and control. Plant Disease, 74, 404-411. https://doi.org/10.1094/PD-74-0404

Hahn, S. K., Howland, A. K., \& Terry, E. R. (1980). Correlated resistance of cassava to mosaic and bacterial blight diseases. Euphytica, 29, 305-311. https://doi.org/10.1007/BF00023215

Hahn, S. K., \& Keyser, J. (1985). Cassava, a basic food of Africa. Outlook Agric, 14, 95-99. https://doi.org/ $10.1177 / 003072708501400207$

Harrison, B. D., Zhou, X., Otim-Nape, G. W., Liu, Y., \& Robinson, D. J. (1997). Role of a novel type of double infection in the geminivirus-induced epidemic of severe cassava mosaic in Uganda. Annals of Applied Biology, 131, 437-48. https://doi.org/10.1111/j.1744-7348.1997.tb05171.x

Hillocks, R. J. (2003). Cassava brown streak virus disease: Summary of present knowledge on distribution, spread, effect on yield and methods of control. In J. P. Legg, \& R. J. Hillocks (Eds.), Proceedings of International Workshop, Mombasa, Kenya, October 27-30, 2002 (p. 23). Aylesford, UK: Natural Resources International Limited.

Hillocks, R. J., \& Jennings, D. L. (2003). Cassava Brown Streak Disease, A Review of Present Knowledge and Research Needs. Int. J. Pest Man., 49, 225-234. https://doi.org/10.1080/0967087031000101061

Hillocks, R. J., Raya, M. D., Mtunda, K., \& Kiozia, H. (2011). Effects of cassava brown streak virus disease on yield and quality of cassava in Tanzania. J. Phytopath., 149, 389-394. https://doi.org/10.1111/j.1439-043 4.2001.tb03868.x

Legg, J. P. (1994). Bemisia tabaci: The whitefly vector of cassava mosaic geminiviruses in Africa: An ecological perspective. African Crop Sci. J., 2, 437-448.

Legg, J. P., \& Thresh, J. M. (2003). Cassava virus disease in Africa. Plant Virology in Sub-Saharan Africa (pp. 517-550).

Legg, J. P., \& Fauquet, C. (2004). Cassava Mosaic Geminiviruses in Africa. Plant Molecular Biology, 56, 585-99. https://doi.org/10.1007/s11103-004-1651-7 
Legg, J. P., Assimwe, P., Sseruwagi, P., \& Brown, J. K. (2006). Changes in the Biology of Bemisia tabaci on cassava in Africa and their impact on Virus Disease Pandemics. Proceedings of $4^{\text {th }}$ International Bemisia Workshop, Dec. 3-6, 2006, Florida, USA.

Legg, J. P, Jeremiah, S. C, Obiero, H. M., Maruthi, M. N., Ndyetabula, I., Okao-Okuja, G., ... Kumar, P. L. (2011). Comparing the regional epidemiology of cassava mosaic and cassava brown streak virus pandemics in Africa. Virus Res., 159, 161-170. https://doi.org/10.1016/j.virusres.2011.04.018

Lema, K. M., Dixon, A., Mahungu, N., Ilona, P., Nluta, S., Lukombo, S., \& Bidiaka, S. (2007). Strategic cassava production rehabilitation in the Democratic Republic of Congo. In N. M. Mahungu, \& V. M. Manyong (Eds.), Advances in Root and Tuber Crops Technologies for Sustainable Food Security, Improved Nutrition, Wealth Creation and Environmental Conservation in Africa (pp. 540-547). Proceedings of the $9^{\text {th }}$ ISTRC-AB Symposium, Mombassa, Kenya, November 1-5, 2007.

Mahungu, N. M, Bidiaka, M., Tata, H., Lukombo, S., \& N'luta, S. (2003). Cassava brown streak disease-like symptoms in Democratic Republic of Congo. ROOTS, 8, 8-9.

Maruthi, M. N., Hillocks, R. J., Mtunda, K., Raya, M. D., Muhanna, M., Kiozia, H., ... Thresh, J. M. (2005). Transmission of cassava brown streak virus by Bemisia tabaci (Gennadius). J. Phytopath., 153, $307-312$. https://doi.org/10.1111/j.1439-0434.2005.00974.x

Mbanzibwa, D. R., Tian, Y. P., Tugume, A. K., Mukasa, S. B., Tairo, F., Kyamanywa, S., ... Valkonen, J. P. T. (2009). Genetically distinct strains of Cassava brown streak virus in the Lake Victoria basin and the Indian Ocean coastal area of East Africa. Arch. Virol., 154, 353-359. https://doi.org/10.1007/s00705-008-0301-9

Monger, W. A., Seal, S, Isaac, A. M., \& Foster, G. T. (2001a). Molecularcharacterization of cassava brown streak virus coat protein. Plant Pathology, 50, 527-534. https://doi.org/10.1046/j.1365-3059.2001.00589.x

Monger, W. A., Alicai, T., Ndunguru, J., Kinyua, Z. M., Potts, P., Reeder, R. H., ... Smith, J. (2010). The complete genome sequence of the Tanzanian strain of Cassava brown streak virus and comparison with the Uganda strain sequence. Archives of Virology, 155(3), 429-433. https://doi.org/10.1007/s00705-009-0581-8

Muimba, K., \& Phuti, K. (1987). Relationship of cassava mosaic severity in planting material to mosaic development, growth and yield of cassava in Zaire. Exp. Agric., 23, 221-225. https://doi.org/10.1017/ S0014479700017026

Mulimbi, W., Phemba, X., Assumani, B., Kasereka, P., Muyisa, S., Ugentho, H., ... Thom, F. E. F. (2012). First report of Ugandan cassava brown streak virus on cassava in Democratic Republic of Congo. New Dis. Rep., 26, 11. https://doi.org/10.5197/j.2044-0588.2012.026.011

Ndunguru, J., Sseruwagi, P., Tairo, F., Stomeo, F., Maina, S., Djinkeng, A., ... Boykin, L. (2015). Analyses of Twelve New Whole Genome Sequences of Cassava Brown Streak Viruses and Ugandan Cassava Brown Streak Viruses from East Africa: Diversity, Supercomputing and Evidence for Further Speciation. PLoS ONE, 10, e0139321. https://doi.org/10.1371/journal.pone.0141939

Nichols, R. F. J. (1950). The brown streak disease of cassava: Distribution climatc effects and diagnostic symptoms. East African Agricultural Journal, 15, 154-160. https://doi.org/10.1080/03670074.1950.116 64727

Omunyin, M. E., Hill, J. H., \& Miller, W. A. (1996). Use of unique RNA sequence-specific oligonucleotide primers for RT-PCR to detect and differentiate soybean mosaic virus strains. Plant Disease, 80, 1170-1174. https://doi.org/10.1094/PD-80-1170

Robertson, N. L., French, R., \& Gray, S. M. (1991). Use of group specific primers and the polymerase chain reaction for the detection and identification of luteoviruses. Journal of General Virology, 72, 1473-1477. https://doi.org/10.1099/0022-1317-72-6-1473

Rwegasira, G. M., Rey, M., \& Nawabu, H. (2011). Approaches to diagnosis and detection of cassava brown streak virus (Potiviridae: Ipomovirus) in field-grown cassava crop. African Scholarly Science Communication Trust, 11(3), 4740. https://doi.org/10.4314/ajfand.v11i3.66626

Storey, H. H. (1936). Virus Diseases of East African Plants VI; A progress report on studies of the disease of cassava. E.A Agric. J., 12, 34-39.

Tata-Hangy, W., Legg, J., Hanna, R., Toko, M., Lema, K. M., Dixon, A., \& Mahungu, N. M. (2007). Incidence and distribution of cassava diseases and pests in the Democratic Republic of Congo. In N. M. Mahungu, \& V. M. Manyong (Eds.), Advances in Root and Tuber Crops Technologies for Sustainable Food Security, 
Improved Nutrition, Wealth Creation and Environmental Conservation in Africa (pp. 540-547). Proceedings of the $9^{\text {th }}$ ISTRC-AB Symposium; Mombassa, Kenya, November 1-5, 2007.

\section{Appendix A}

\section{Description of visual diagnostic scale of CBSD}

\begin{tabular}{|c|c|c|c|c|}
\hline Disease parameter & Plant part assessed & Symptomatic/damaged & Score scale & Description \\
\hline \multirow{15}{*}{ CBSD severity } & \multirow{5}{*}{ Foliar } & $0 \%$ & 1 & None of the leaves has chlorosis characteristic for CBSD \\
\hline & & $1-5 \%$ & 2 & Slight chlorotic spots characteristic of CBSD seen on leaves \\
\hline & & $5-12 \%$ & 3 & CBSD chlorotic spots/blotches easily observable on leaves \\
\hline & & $12-30 \%$ & 4 & Appreciable CBSD chlorotic spots/blotches seen on leaves \\
\hline & & $30-100 \%$ & 5 & Very severe chlorotic/necrotic blothes and leaf wilt \\
\hline & \multirow{5}{*}{ Stem } & $0 \%$ & 1 & No necrotic spot or lesion is seen on stem \\
\hline & & $1-5 \%$ & 2 & Slight chlorotic spots on tender portion of the stem \\
\hline & & $5-12 \%$ & 3 & Necrotic spots are numerous, coalesced to small lesions \\
\hline & & $12-30 \%$ & 4 & Severe necrotic lesions enlarged into streaks \\
\hline & & $30-100 \%$ & 5 & Severe necrotic lesions, streaks, withering and die-back \\
\hline & \multirow{5}{*}{ Root } & $0 \%$ & 1 & None of the roots has necrosis characteristic for CBSD \\
\hline & & $1-5 \%$ & 2 & Small portion of roots bears necrotic spots \\
\hline & & $5-12 \%$ & 3 & Appreciable proportion of the roots is obviously necrotic \\
\hline & & $12-30 \%$ & 4 & Roots mostly necrotic, not suitable for consumption \\
\hline & & $30-100 \%$ & 5 & Roots are almost/totally necrotic, started \\
\hline
\end{tabular}

\section{Copyrights}

Copyright for this article is retained by the author(s), with first publication rights granted to the journal.

This is an open-access article distributed under the terms and conditions of the Creative Commons Attribution license (http://creativecommons.org/licenses/by/4.0/). 